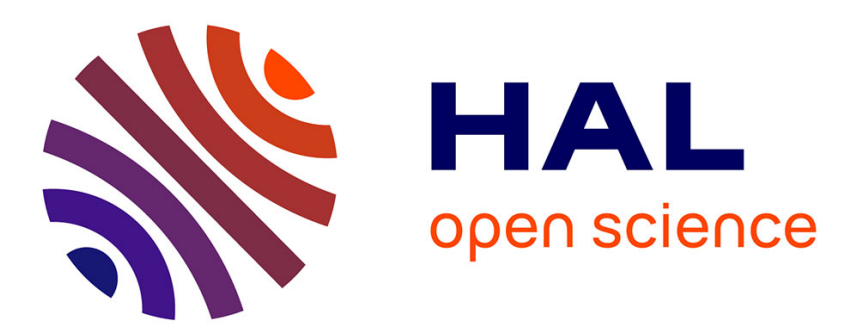

\title{
Effects of cisplatin on matrix metalloproteinase-2 in transformed thyroid cells
}

\author{
L. Urso, A. Muscella, N. Calabriso, C. Vetrugno, E. Jimenéz, M. Montiel, S. \\ Marsigliante
}

\section{- To cite this version:}

L. Urso, A. Muscella, N. Calabriso, C. Vetrugno, E. Jimenéz, et al.. Effects of cisplatin on matrix metalloproteinase-2 in transformed thyroid cells. Biochemical Pharmacology, 2010, 79 (6), pp.810. 10.1016/j.bcp.2009.10.013 . hal-00556271

\section{HAL Id: hal-00556271 https://hal.science/hal-00556271}

Submitted on 16 Jan 2011

HAL is a multi-disciplinary open access archive for the deposit and dissemination of scientific research documents, whether they are published or not. The documents may come from teaching and research institutions in France or abroad, or from public or private research centers.
L'archive ouverte pluridisciplinaire HAL, est destinée au dépôt et à la diffusion de documents scientifiques de niveau recherche, publiés ou non, émanant des établissements d'enseignement et de recherche français ou étrangers, des laboratoires publics ou privés. 


\section{Accepted Manuscript}

Title: Effects of cisplatin on matrix metalloproteinase-2 in transformed thyroid cells

Authors: L. Urso, A. Muscella, N. Calabriso, C. Vetrugno, E. Jimenéz, M. Montiel, S. Marsigliante

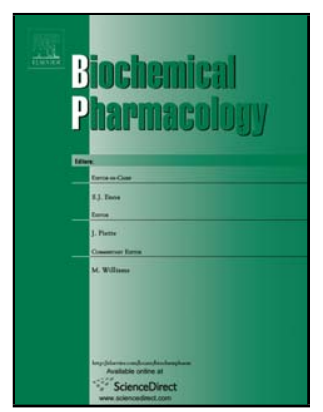

PII:

S0006-2952(09)00928-9

DOI: doi:10.1016/j.bcp.2009.10.013

Reference: BCP 10359

To appear in: $B C P$

Received date: 23-8-2009

Revised date: 14-10-2009

Accepted date: $15-10-2009$

Please cite this article as: Urso L, Muscella A, Calabriso N, Vetrugno C, Jimenéz E, Montiel M, Marsigliante S, Effects of cisplatin on matrix metalloproteinase-2 in transformed thyroid cells, Biochemical Pharmacology (2008), doi:10.1016/j.bcp.2009.10.013

This is a PDF file of an unedited manuscript that has been accepted for publication. As a service to our customers we are providing this early version of the manuscript. The manuscript will undergo copyediting, typesetting, and review of the resulting proof before it is published in its final form. Please note that during the production process errors may be discovered which could affect the content, and all legal disclaimers that apply to the journal pertain. 


\title{
EFFECTS OF CISPLATIN ON MATRIX METALLOPROTEINASE-2 IN TRANSFORMED THYROID CELLS
}

\section{URSO L, MUSCELLA A, CALABRISO N, VETRUGNO C, ( $\left.{ }^{1}\right)$ JIMENÉZ E, ( $\left.{ }^{1}\right)$ MONTIEL $M$, and $\left({ }^{*}\right)$ MARSIGLIANTE S}

Department of Biological and Environmental Sciences and Technologies (Di.S.Te.B.A.), Università del Salento - Lecce, Italy

(1)Department of Biochemistry and Molecular Biology, University of Malaga - Malaga, Spain.

$\left(^{*}\right)$ Corresponding author: S. Marsigliante, Laboratory of Cellular Physiology, Department of Biological and Environmental Sciences and Technologies (Di.S.Te.B.A.), Università del Salento - Lecce, Italy; email: santo.marsigliante@unisalento.it

\section{Running title: EFFECTS OF CISPLATIN ON MMP-2}

\author{
$N^{\circ}$ of figures: 4
}

1 - Urso et al. Effects of cisplatin on MMP-2 


\section{ABSTRACT}

We investigated the effects of cisplatin (cisPt) on matrix metalloproteinase-2 (MMP-2) gelatinolitic activity in transformed PC E1Araf rat thyroid cells. Cells incubated with increasing cisPt concentrations showed dose- and time-dependent decrease of the MMP-2 protein and activity. CisPt provoked the translocation from the cytosol to the plasma membrane of atypical protein kinase C-zeta (PKC- $\zeta)$ and the activation of PKB/AKT. The effect of cisPt on MMP-2 was dependent on PKC- $\zeta$ activation since it was potentiated by a myristoylated PKC- $\zeta$ pseudo substrate peptide or by $\mathrm{PKC}-\zeta$ down regulation by siRNA. Moreover, MMP-2 activity modulation by cisPt was also dependent on PKB/AKT activation since it was decreased by PKB/AKT down regulation by siRNA or by pharmacological inhibition of PI3K, thus indicating the importance of the balance of $\mathrm{PKB} / \mathrm{AKT}$ and PKC- $\zeta$ in regulating the cisPt effect on MMP-2 activity. The PC E1Araf cells displayed a migratory capacity that was blocked by MMP-2 down regulation using siRNA or pharmacological inhibition. The inhibition of cell migration was also obtained with cisPt; in cisPt-treated cells the administration of MMP-2 active protein was able to restore cell migration capacity. In conclusion, the decrease of MMP-2 secretion after cisPt was allowed by PKB/AKT and counteracted by PKC- $\zeta$; the cisPt-provoked inhibition of MMP-2 secretion ended in reduction of cell migration.

\footnotetext{
2 - Urso et al. Effects of cisplatin on MMP-2
} 


\section{INTRODUCTION}

Matrix metalloproteinases (MMPs) are a family of more than 21 zinc-dependent endopeptidases, which mediate the homeostasis of the extracellular matrix (ECM) and are up regulated in almost every type of human cancer. Whereas some MMPs are expressed mainly by cancer cells, others are expressed by cells within the tumour microenvironment. This indicates that MMPs are altered in various aspects of malignant phenotype, therefore representing promising therapeutic targets [1]. Matrix metalloproteinase-2 (MMP-2) degrades various ECM components including type I and type IV collagens, fibronectin, laminin, and elastin. In addition, MMP-2 is a potent gelatinase [2]. The chemotherapeutic agent cisplatin (cis-diamminedichloroplatinum; cisPt), widely employed for treatment of human cancer, is a potent inducer of growth arrest and/or apoptosis in most cell types. Anti-invasive properties of cisPt associated with decrease in MMP-2 activity have been reported [3-5] with the underlying mechanisms still being poorly understood. Anyway, as regards to that several signalling transduction pathways that can be activated by cisPt treatment, such as mitogen activated protein kinase (MAPK) pathway components, have been correlated to MMPs activation and expression [6,7]. Thyroid carcinomas produce elevated levels of MMP-2, and MMP-2 activation correlates with the presence of lymph node metastases [8]. We recently showed, in normal rat thyroid $\mathrm{PC} \mathrm{Cl3}$ cell line, the enhancement of MMP-2 expression and activity in cisPt signalling, the role of oxidant stress in such activation and the MMP-2-mediated activation of the receptor for the epidermal growth factor (EGFR), providing some insights into the understanding of cisPt effect on normal cells [9]. We here looked at the MMP-2 response to cisPt treatment in tumourigenic PC E1Araf thyroid cell line. PC E1Araf is a tumourigenic cell line derived from $\mathrm{PC} \mathrm{Cl3}$ cells transformation by a combination of the adenovirus E1A gene and the raf oncogene $[10,11]$. These cells do not express the typical markers of thyroid differentiation, and are insensitive to thyrotropin stimulation for their growth. Our study focussed on the role that the PKCs/ERK and PI3K/AKT signal transduction pathways may have in cisPt's effects on MMP-2 expression inasmuch as we demonstrated previously that cisPt brings about a signalling mediated by these pathways in PC E1Araf cells [12]. The role of MMP-2 on

3 - Urso et al. Effects of cisplatin on MMP-2 
cell motility was also addressed in order to highlight a function of MMP-2 in the regulation of cancer cell invasion. The data demonstrated that, differently from $\mathrm{PC} \mathrm{Cl}$, cisPt reduces MMP-2 expression and activity in PC E1Araf cells, and that this effect is enhanced by PKC- $\zeta$ antagonism and abrogated by PKB/AKT antagonism.

\section{MATERIALS AND METHODS}

\subsection{Materials}

Coon's modified Ham's F12 medium, foetal bovine serum (FBS) and glutamine were from Euroclone (Paignton, UK). Myristoylated PKC- $\zeta$ pseudo substrate peptide (MyrSIYRRGARRWRKL) (ל-PS), MMP-2 inhibitor I, MEK1 inhibitor PD98059 and the MMP-2 active protein from mouse calvariae were obtained from Calbiochem (Darmstadt, Germany). Antibodies used in western analyses to Akt/PKB (Sc-8312, recognises all isoforms), PKC- $\zeta$ (Sc-876), MMP-2 (sc-10736), $\beta$-actin (sc-130657) and alpha subunit of $\mathrm{Na}+\mathrm{K}+\mathrm{ATPase}$ (sc-28800), goat anti-rabbit lgG conjugated with peroxidase, were from Santa Cruz Biotechnology (Santa Cruz, CA, USA). Enhanced chemiluminescence (ECL) was from Amersham Life Sciences Inc. (Amersham Italy, Milan).

\subsection{Cell culture}

PC E1Araf cells were grown in Coon's modified Ham's F12 medium, supplemented with $5 \%$ foetal bovine serum, containing L-glutamine $(2 \mathrm{mM})$ and gentamicin $(50 \mu \mathrm{g} / \mathrm{ml})$. The cells were maintained in a water-saturated atmosphere of $5 \% \mathrm{CO}_{2}$ and $95 \%$ air at $37^{\circ} \mathrm{C}$.

\subsection{MMP Gelatin Zymography}

After cisPt treatment, the culture medium was collected and PC E1Araf cells were washed with PBS and harvested by scrapping in $0.1 \mathrm{M}$ Tris/ $\mathrm{ClH}$ containing $0.2 \%$ Triton X-100. Both conditioned medium and cell lysates were centrifuged at 14,000 rpm for 5 $\min$ at $4^{\circ} \mathrm{C}$ to remove cells and debris. Each sample was mixed with equal amounts of SDS sample buffer and electrophoresed on $10 \%$ polyacrylamide gels containing $1 \mathrm{mg} / \mathrm{ml}$ gelatin as the protease substrate. Following electrophoresis, gels were placed in Triton

4 - Urso et al. Effects of cisplatin on MMP-2 
X-100 solution (50 mM Tris/HCl pH 7.4, containing 2.5\% Triton $\mathrm{X}-100)$ for $1 \mathrm{~h}$ to remove SDS, and then incubated for $16-18 \mathrm{~h}$ at $37^{\circ} \mathrm{C}$ in developing buffer (50 mM Tris base, 200 $\mathrm{mM} \mathrm{NaCl}, 5 \mathrm{mM} \mathrm{CaCl}_{2}$, and 1\% Triton X-100, $\mathrm{pH} \mathrm{7,4).} \mathrm{After} \mathrm{incubation,} \mathrm{gels} \mathrm{were}$ stained in 30\% methanol, 10\% acetic acid, and 0.5\% w/v coomassie brilliant blue for $1 \mathrm{~h}$ followed by destaining.

\subsection{Preparation of cellular fractions and western blot analysis}

The preparation of whole cell extracts, membrane and cytosol fractions and the determination of the purity of the cell membrane fraction used for immunoblotting, were performed as previously reported [13]. Akt/PKB (isoforms 1,2,3), beta-actin, alphasubunit of $\mathrm{Na}^{+} / \mathrm{K}^{+}$-ATPase, PKC- $\zeta$ and MMP-2 proteins were detected by western blot analysis using specific antibodies.

\subsection{Cytotoxicity assay}

Cells at $70-80 \%$ confluency were trypsinised (0.25\% trypsin with $1 \mathrm{mM}$ EDTA), washed, re suspended in growth medium, and seeded in 96-well plates at $10^{4} \mathrm{cell} / \mathrm{ml}$ cell per well. Cytotoxicity assay was performed using MTT (3-(4,5-dimethylthiazol-2-yl)-2,5-diphenol tetrazolium bromide) as previously described [12].

\subsection{Cell migration assay}

Migration experiments were carried out using the Fluoroblok system, using 24-well fluorescence-opaque membrane inserts, as previously described [14]. The cells were grown to confluence and labelled in situ with $5 \mu \mathrm{g} / \mathrm{ml}$ calcein- $\mathrm{AM}$ for $2 \mathrm{~h}$ at $37^{\circ} \mathrm{C}$. The monolayer was trypsinized and the cells were suspended in medium supplemented with $0.1 \% \mathrm{BSA}$ and added to $8 \mu \mathrm{m}$ Falcon HTS fluoroblok insert at a density of $5 \cdot 10^{5}$ cells/insert. Medium containing 10\% FBS was added to the lower chamber as a chemoattractant. After incubation at $37^{\circ} \mathrm{C}$ real time kinetics of cell migration was determined by taking readings at different times. Fluorescence of cells that had migrated through the inserts was measured on the Fluorescence Microplate Reader (FL600FA, BIO-TEK instruments, Winooski, VT, USA) using an excitation and emission wavelength

5 - Urso et al. Effects of cisplatin on MMP-2 
of 485 and $530 \mathrm{~nm}$, respectively. The number of migrated cells was calculated as the fluorescent ratio of treated to untreated cells. Some membrane inserts containing the migrated cells, treated or not with $100 \mu \mathrm{M}$ cisplatin, were mounted on a Nikon Eclipse E800 epi-fluorescence microscope (Nikon Instruments S.p.a., Calenzano (FI)) and representative images were obtained.

\subsection{Design and preparation of small interfering RNA (siRNA)}

siRNAs for PKC- $\zeta$, PKB/AKT and MMP-2 were prepared by an in vitro transcription method as previously described [13]. Briefly, siRNAs were prepared by an in vitro transcription method. Initially, four siRNA- $\zeta$ target sites specific to rat PKC- $\zeta$ mRNA, and three siRNA-MMP-2 target sites specific to rat mRNAs as determined by blast analysis, were chosen. A nonspecific siRNA (siRNA-NS) was also designed to serve as a negative control. For each siRNA, sense and antisense templates were designed based on each target sequence and partial T7 promoter sequence. All template oligonucleotides were chemically synthesized and PAGE purified. In vitro transcription, annealing, and purification of siRNA duplexes were performed using the protocol supplied with the T7 RiboMAX Express RNAi System (Promega Corporation, Madison, WI, USA). Approximately $2 \mu \mathrm{g}$ of each single-strand (ss) transcription template was first annealed with the T7 promoter and filled in by Klenow DNA polymerase to form doublestrand transcription templates. For preparation of each siRNA duplex, transcription reactions were first performed with separated antisense and sense templates using the T7 RNA polymerase provided with the kit and then annealed to form siRNA duplexes. Then, the siRNA duplex was treated with DNase and RNase to remove the extra nucleotides of transcribed siRNA to meet the structural 3'UUU overhang and 5' phosphate requirement. PKC- $\zeta$, PKB/AKT and MMP-2 immunoblottigs were performed $24 \mathrm{~h}$ posttransfection to determine the efficiency of siRNA incorporation in PC E1Araf cells and to measure PKC- $\zeta$, PKB/AKT and MMP-2 expressions. Quantitative analysis of PKC- $\zeta$ and MMP-2 expressions, as measured by intensity of PKC- $\zeta$ and MMP-2 immunoreactivities, in siRNA- $\zeta$-transfected and in siRNA-MMP-2-transfected PC E1Araf, revealed a higher reduction in PKC- $\zeta, A K T$ and MMP-2 expressions, with the

6 - Urso et al. Effects of cisplatin on MMP-2 
following sense RNA sequence: 5'-GCUGAGAUCUGUAUCGCUC-3' (PKC-ל), 5'UGCCCUUCUACAACCAGGATT-3' (PKB/AKT1 and PKB/AKT2), 5'UGCCUUUCUACAACCAGGATT-3' (PKB/AKT3, [15]) and 5'UACCGUUCCACACCACACGU-3' (MMP-2). Such reductions in PKC- $\zeta$, PKB/AKT and MMP-2 expressions were not revealed in nonsense siRNA (SiRNA-NS)-transfected cells designed to serve as a negative control (non-specific siRNA, sequence 5'AAGTTCTCCGAAGTGTGAGAA-3' for PKC-ל, 5'-CGGTTCTTCGTAGTGTGCGAA-3' for PKB/AKT and 5'-CCAGUAGUUGGACCUCGUUGG-3' for MMP-2).

\subsection{SiRNA transfection}

The cells (50-70\% confluence) were transfected with siRNA duplexes using the protocol supplied with the CodeBreaker siRNA transfection reagent (Promega, Milan, Italy). Briefly, transfection reagent was first diluted into Coon's modified Ham's F12 medium without serum and antibiotics for about $15 \mathrm{~min}$, and then the siRNA- PKC- $\zeta$ or siRNAPKB/AKT, siRNA-MMP-2, and siRNA-NS duplex were added to the medium to form a lipid-siRNA complex. Following additional 15-min incubation, transfection was initiated by adding the lipid-siRNA complex to 6-well plates. The final concentration of siRNAs was $10 \mathrm{nM}$.

\subsection{Reverse transcriptase-polymerase chain reaction (RT-PCR)}

Total RNA was extracted from PC E1Araf cells using the SV Total RNA Isolation System (Promega, Milan, Italy) according to the manufacturer's instructions. For RT-PCR $1 \mu \mathrm{g}$ total RNA was reverse transcribed in: $50 \mathrm{mM}$ Tris/ $\mathrm{HCl}(\mathrm{pH} 8.3), 75 \mathrm{mM} \mathrm{KCl}, 3 \mathrm{mM}$ $\mathrm{MgCl}$, $10 \mathrm{mM}$ DTT, $0.5 \mathrm{mM}$ dNTP; oligo(dT)15 primer $0.5 \mu \mathrm{g}$ and $15 \mathrm{u}$ M-MLV RT (Promega). The amplification profile consisted of denaturation at $95^{\circ} \mathrm{C}$ for $30 \mathrm{sec}$, annealing at $57^{\circ} \mathrm{C}$ for $60 \mathrm{sec}$ and extension at $72^{\circ} \mathrm{C}$ for $90 \mathrm{sec}$ for 30 cycles. Reaction products were resolved by electrophoresis through 1\% agarose gels and stained with ethidium bromide. Contamination by genomic DNA in sample RNA was excluded by amplifying the sample RNA directly by PCR without reverse transcriptase.

7 - Urso et al. Effects of cisplatin on MMP-2 
Real-time PCR was performed using a BioRad iQ iCycler Detection System (BioRad Laboratories, Ltd., Milan, Italy) with SYBR green fluorophore (SyberGreen Supermix; BioRad Laboratories, Ltd.) in the presence of $2 \mu \mathrm{M}$ of specific primers. B-actin was used as a standard housekeeping gene. Primers for MMP-2 were sense 5'-CCACGTGACAAGCCCATGGGGCCCC-3' and 5'GCAGCCTAGCCAGTCGGATTTGATG-3' and for B-actin were sense 5'TCAGAAGGACTCCTATGTGG-3' and antisense 5'-TCTCTTTGATGTCACGCACG-3'. After denaturation for $3 \mathrm{~min}$ at $93^{\circ} \mathrm{C}, 40$ cycles of amplification were performed using a model 9700 thermocycler (Perkin Elmer, Foster City, CA, USA), followed by final extension of $5 \mathrm{~min}$ at $72^{\circ} \mathrm{C}$. The cycling parameters were: denaturation for $45 \mathrm{~s}$ at $93^{\circ} \mathrm{C}$, annealing for $45 \mathrm{~s}$ at $58^{\circ} \mathrm{C}$, extension for $1.5 \mathrm{~min}$ at $72^{\circ} \mathrm{C}$. A melt curve analysis was performed following every run to ensure a single amplified product for every reaction. Relative MMP-2 gene expression was determined using the $2^{-\otimes \otimes C T}$ method and normalised to ß-actin expression.

\section{RESULTS}

\subsection{CisPt induced regulation of MMP-2 activity in rat thyroid cells}

Gelatin zymography showed that baseline MMP-2 activity only was detectable in cell lysates and in growth media from PC E1Araf cells (Fig 1.A); cisPt administration (10 and $100 \mu \mathrm{M}$, given for 1, 2 and $4 \mathrm{~h}$ ) decreased MMP-2 activity (Fig 1.B and C). In PC E1Araf cell lysates, western analysis demonstrated that MMP-2 protein level decreased after cisPt treatment (Fig 1.D), whilst MMP-2 PCR did not show any significant effect of cisPt (Fig 1.E and Fig 1.F for real-time PCR data), suggesting that the regulation was at the protein expression level.

\subsection{Role of intracellular signalling in cisPt-provoked MMP-2 regulation}

As shown previously, PCE1Araf cells have a high basal phosphorylated ERK1/2 [12]; to investigate the relationship between ERK1/2 pathway and MMP-2 regulation, cells were

8 - Urso et al. Effects of cisplatin on MMP-2 
treated with the MEK inhibitor PD98059 $(15-30 \mu \mathrm{M})$ for $30 \mathrm{~min}$. In un-stimulated cells PD98059 provoked a decrease in MMP-2 activity (Fig 2.A). The pre incubation with PD98059 prior to cisPt treatment showed a further decrease of MMP-2 activity and protein in PC E1Araf cells (Fig 2.B and C). As previously shown, in PC E1Araf cells treated with cisPt, ERK1/2 activation is due to PKC- $\zeta$ [12]. In order to understand the role of PKC in the cisPt-evoked MMP-2 regulation, GF109203X (0.1-10 $\mu \mathrm{M})$, an inhibitor of all PKC isoforms, was used. Indeed, GF109203X, at the highest dose, provoked a further decrease in MMP-2 activity in PC E1Araf cells (Fig 2.D); similarly, $10 \mu \mathrm{M}$ GF109203X reduced the basal MMP-2 activity (Fig 2.D). The involvement of other PKCs was checked pre-treating the PC E1Araf cells with Gö6976 (0.1 and $1 \mu \mathrm{M})$, a conventional PKC inhibitor, or with rottlerin (10 and $20 \mu \mathrm{M})$, an inhibitor of PKC- $\delta$, which is also activated in response to cisPt administration. As shown in Fig. 2E and F, these inhibitors did not have any effect on the MMP-2 reduction provoked by cisPt, thus highlighting a role of atypical

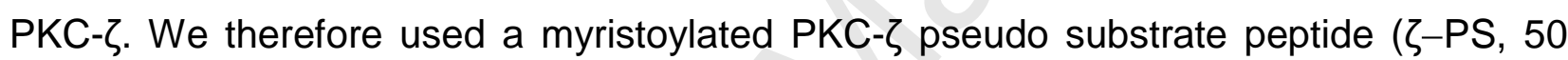
and $100 \mu \mathrm{M}$ ) in order to specifically inhibit PKC- $\zeta$ and to confirm its role in PC E1Araf cells. As shown in Fig 2.G, PS- $\zeta$ provoked a further decrease in PC E1Araf cells treated with cisPt. Furthermore, a down regulation of PKC- $\zeta$ isoform by small interfering RNA was performed. Preliminary experiments by western blotting demonstrated that siRNAPKC- $\zeta$ was able to reduce PKC- $\zeta$ expression and that siRNA-NS had no silencing effect on PKC- $\zeta$ expression at $24 \mathrm{~h}$ posttransfection (Fig 3.A). The siRNA- PKC- $\zeta$ reduced both cisPt-induced MMP-2 and basal MMP-2 activity (Fig 3.B). Fig 3.C shows that upon cisPt exposure, an intracellular-to-membrane translocation of PKC- $\zeta$ occurred, confirming activation of this isoform. We address how activation of PKC- $\zeta$ and ERK by cisPt treatment would down regulate MMP2 expression and activity. In a previous work we demonstrated that, in PC E1Araf cell line, cisPt provoked a transient PKB/AKT phophorylation, which was maximal at 1 and $2 \mathrm{~h}$, and declined to the basal level at $3 \mathrm{~h}$ [16]. In order to check whether PKB/AKT had a role in cisplatin regulation of MMP-2 activity, the cells were pre-incubated with an inhibitor of PI3K/PKB pathway, LY294002 $(50 \mu \mathrm{M})$. The result showed that LY294002 was able to increase the activity of MMP-2 in cisplatin-stimulated PC E1Araf cells, thus suggesting a role of PKB/AKT in the control of

9 - Urso et al. Effects of cisplatin on MMP-2 
MMP-2 activity (Fig 3.D). To confirm the data, a down regulation of PKB/AKT isoforms by small interfering RNA was performed. Preliminary experiments by western blotting demonstrated that siRNA-PKB/AKT was able to reduce PKB/AKT expression and that siRNA-NS had no silencing effect on PKB/AKT expression at $24 \mathrm{~h}$ posttransfection (Fig 3.E). The siRNA-PKB/AKT increased cisPt-induced MMP-2 activity (Fig 3.D).

\subsection{Effect of cisPt on migratory capacity of rat thyroid cells.}

Boyden chamber assays were done to assess the migratory capability of PC E1Araf cells. The time-course analysis showed that PC E1Araf cells had migratory capability through the membrane. The presence of cisPt $(10$ and $100 \mu \mathrm{M})$ in the cell culture medium decreased the motility of PC E1Araf cells in a time- and dose-dependent manner, with a maximum effect visible after $3 \mathrm{~h}$ treatment (Fig 4.A). To test whether such effect was due to inhibition of MMP-2 activity, a down regulation of MMP-2 by siRNA was performed (Fig 4.B). As showed in Fig 4C, an inhibition of cell motility evaluated after $3 \mathrm{~h}$ was observed. This inhibition was also obtained when cells were treated with MMP-2 inhibitor I or when a down regulation of PKC- $\zeta$ expression was performed by siRNA. Mouse MMP-2 active protein added to cisPt-stimulated cells restored cell migration capacity (Fig 4.C). In order to understand whether MMP-2 was implicated in cisPt induced apoptosis, a down regulation of MMP-2 by siRNA was performed prior to stimulation with cisPt $100 \mu \mathrm{M}$ for $4 \mathrm{~h}$, and cell viability was evaluated by MTT test. Depletion of MMP-2 provoked no significant effects in cisPt-provoked cytotoxicity in PC E1Araf cells (Fig 4.D). Furthermore, mouse MMP-2 active protein added to cells did not significantly affect cell viability.

In order to confirm that MMP-2 did not contribute to cisPt induced apoptosis, as is the case of the PC Cl3, where MMP-2 enhanced the apoptotic effects of cisPt through the activation of EGFR [9], PC E1Araf cells were incubated with $100 \mu \mathrm{M}$ cisPt for 2, 4 and $24 \mathrm{~h}$ and the cleavage patterns of caspase-7 and poly(ADP-ribose) polymerase (PARP) were analysed by Western blotting. PARP, a 113-kDa nuclear protein, has been shown to be one of the first proteins specifically cleaved by caspase-3 and -7 during apoptosis. Therefore, PARP cleavage was examined by Western blotting of proteins obtained from

10 - Urso et al. Effects of cisplatin on MMP-2 
isolated nuclei. As shown in Fig 4.E cisPt significantly increased the amounts of cleaved PARP only after $24 \mathrm{~h}$. Similarly, the conversion of procaspase-7 into the activated forms of low molecular mass p20 was observed in cisPt-treated cells (Fig 4.E) but only after 24 $\mathrm{h}$ of treatment, thus confirming that the early signs of apoptosis induction are not evident during the first hours of cisPt treatment. As positive controls, we used $100 \mu \mathrm{M}\left[\mathrm{Pt}\left(\mathrm{O}, \mathrm{O}^{\prime}-\right.\right.$ acac)( $\mathrm{Y}$-acac)(DMS)], a $\mathrm{Pt}(\mathrm{II})$ analogue able to provoke the early signs of apoptosis induction $1 \mathrm{~h}$ after addition in both HeLa [17] and MCF-7 [18] cell lines. As shown in Fig 4.E, the increase of the amounts of cleaved PARP and the conversion of procaspase-7 into the activated forms were already evident after $2 \mathrm{~h}$ treatment.

\section{DISCUSSION}

MMPs play a major role in physiological and pathological processes such as embryonic development, differentiation, apoptosis, immune surveillance, tumour angiogenesis, invasion and metastasis [19]. Under physiologic conditions, MMPs activity is tightly controlled, and primary models of regulation include transcriptional control, zymogen activation and dynamic inhibition by tissue inhibitors of metalloproteinases [20]. The metastatic and invasive potential of many cancers also depends on the expression of MMPs and MMP-2 over expression and activity associated with the invasive potential of human tumours [21]. With the present study we demonstrated that basal MMP-2 activity only is detectable in culture media and cell lysates from PC E1Araf cell line, and that expression and activity of MMP-2 was decreased by cisPt in a dose- and timedependent manner (Fig 1), accordingly to data obtained in small-cell lung cancer cells [5] but not to those showed in parental normal PC Cl3 cells [9]. Thus, one could speculate that the MMP-2 is a general target of cisPt in thyroid cells; however, cisPt caused differential effects on MMP-2 in both normal and transformed thyroid cells, and these discrepancies may be accounted for in part by the presence of high basal level of activated ERK1/2. In PC E1Araf cells the effect of cisPt was evident in the first hours and did not affect the mRNA level of MMP-2 (Fig 1.E and F). The mitogen activated protein kinase (MAPK) superfamily, which includes ERK1/2, JNKs, and p38 kinase, plays an important role in the regulation of MMPs expression [6; 22]. MMP-2 expression 
and activity is correlated to ERK phosphorylation [23; 24], and blockade of ERK pathway suppressed expression of MMPs [25]. In addition, activation of the ERK pathway in tumour cells correlated with cancer cell invasive and metastatic phenotype [22; 25]. In contrast, an inhibitory effect of ERK1/2 on MMP-2 expression was shown in different cell systems [26]. To determine whether a correlation between ERK pathway and MMP-2 activity was also present in PC E1Araf cells, we performed gelatine zymography analysis in PC E1Araf cells with ERK inhibited by PD98059, since PC E1Araf cells have, in control condition, a high basal phosphorylated ERK1/2 level [12; 16]. When PC E1Araf cells were treated with PD98059, a significant decrease in MMP-2 secretion in conditioned medium was observed (Fig 2.A) suggesting that in PC E1Araf cells MMP-2 expression is regulated by ERK1/2. Consistently, in PC E1Araf cells pre-incubated with PD98059 and then stimulated with cisPt, a further decrease of MMP-2 secretion in conditioned medium and cell lysates was observed (Fig 2.B and C). In a previous work we demonstrated that, in PC E1Araf cells, PKC- $\zeta$ acts upstream to cisPt-induced ERK1/2 phoshorylation [12]. For this reason we looked at the effects of PKC- $\zeta$ on MMP2 modulation by cisPt. Indeed, when PKC- $\zeta$ in PC E1Araf cells was pharmacologically inhibited by high doses of GF109203X, known to inhibit at such doses the atypical PKC isoforms [27] or by the use of the myristoylated PKC- $\zeta$ pseudo substrate peptide ( $\zeta-P S)$, we observed an inhibition in MMP-2 secretion and activity both in unstimulated and cisPt-treated cells (Fig 2.D and G). The same results were obtained when PKC- $\zeta$ was down regulated by siRNA (Fig 3.A and B). The data are consistent with other showing that MMP-2 is modulated by phosphorylation and that PKC may be, in vivo, a regulator of this protease [28], PKC- $\zeta$ included [29]. Indeed, we found that in response to cisPt administration a subsequent PKC- $\zeta$ activation occurred after as soon as 15 min (Fig 3.C). We also showed previously that in PC-E1Araf cells the activation of ERK decreased greatly in the presence of inhibitors of both PI3K and PKC- $\zeta$ activities, thus suggesting that $\mathrm{PI} 3 \mathrm{~K} / \mathrm{Akt}$ and $\mathrm{PKC}-\zeta$ signalling play a role in cisPt provoked phosphorylation of ERK [12]. Pharmacological (by LY294002) and molecular (by siRNA) data showed in Fig 3.D suggest that the PI3K/AKT pathway, activated upon cisPt administration, decreased the MMP-2 activation. PC E1Araf cells express high basal

12 - Urso et al. Effects of cisplatin on MMP-2 
levels of MMP-2, probably because of the intrinsic ERK activity. Overall, cisPt administration decreased the activity of MMP-2 (even though increased the activity of ERK) probably through the operativity of PI3K/AKT which, whilst increasing further the phosphorylation of ERK, also potently inhibited MMP-2 activity.

PC E1Araf cells showed the ability to migrate through transwell chamber (Fig 4.A); generally, cell migration involves at least three independent and highly coordinated processes: (1) adhesion to extracellular matrix; (2) cytoskeleton reorganization and (3) invasion, that involves the degradation of matrix proteins also by MMP-2, MMP-9, and MMP-14 [30]. Indeed, we here showed that MMP-2 has a role in motility capacity of PC E1Araf cells since both its inhibition by the MMP-2 inhibitor I or by siRNA significantly decrease cell migration (Fig 4.C). Furthermore, cisPt was also able to inhibit PC E1Araf cells motility (Fig 4.A), and the administration of MMP-2 active protein to cisPt-treated cells restored such motility, further suggesting that in the cisPt-induced decrease of cell migration MMP-2 is involved (Fig 4.C). MMPs are able to modulate several signalling pathways; for example, MMP-2, MMP-7 and MMP-9 can cleave cell surface pro-HBEGF and liberate the soluble active growth factor [31]. MMPs can also modulate apoptosis by cleaving death ligands (TNF-alpha and FasL) and their receptors that trigger apoptosis by acting in an autocrine or paracrine manner [32]. Noteworthy, in normal rat thyroid PC Cl3 cells, MMP-2 enhanced cell death pathway through the activation of EGFR signalling [9]. However, the inhibition of MMP-2 did not affect PC E1Araf sensitivity to cisPt (Fig 4.D), suggesting that MMP-2 has no role in cell death pathway, and cisPt was not able to induce apoptosis, at least during the first 4 hours of treatment (Fig 4.E). To confirm the lack of effects of MMP-2 in cisPt-induced apoptosis, cells were stimulated with MMP-2 active protein, but MMP-2 protein was not able to induce cells death in PC E1Araf cells (Fig 4.C).

In conclusion, the results obtained in the transformed PC E1Araf cells differ considerably from those obtained in normal PC Cl3 cells both for the overall effect of cisPt and for the intracellular signalling pathways involved. Indeed, while cisPt increased MMP-2 activity and secretion in normal PC Cl3 cells [9], it was able to decrease MMP-2 expression and to bring about a signalling pathway ending in cell motility control in transformed PC

13 - Urso et al. Effects of cisplatin on MMP-2 
E1Araf cells. These data are the first to show that MMP-2 expression and function in PC E1Araf cells is differently regulated by PKC-Z/ERK and PI3K/AKT pathways. The concept of MMP-2 as a target of cisPt may be important in thyroid cancer therapy.

\section{REFERENCES}

[1] Sasanelli R, Boccarelli A, Giordano D, Laforgia M, Natile G, Cardellicchio C, et al. Platinum complexes can inhibit matrix metalloproteinase activity: platinumdiethyl[(methylsulfinyl)methyl]phosphonate complexes as inhibitors of MMP-2, $-3,-9$, and -12. J Med Chem 2007;50:3434-3441.

[2] Mignatti P, Rifkin DB. Nonenzymatic interactions between proteinases and the cell surface: novel roles in normal and malignant cell physiology. Adv Cancer Res 2000;78: 103-157.

[3] Chintala SK, Ali-Osman F, Mohanam S, Rayford A, Go Y, Gagercas E, et al. Effect of cisplatin and BCNU on MMP-2 levels in human glioblastoma cell lines in vitro. Clin Exp Metastasis 1997;15:361-367.

[4] Mabuchi S, Ohmichi M, Nishio Y, Kimura A, Ohta T, Saito M, et al. Inhibition of NFkappaB increases the efficacy of cisplatin in in vitro and in vivo ovarian cancer models. J Biol Chem 2004;279:23477-23485.

[5] Morikawa T, Shibuya M, Sakai S, Kudo S. Effect of anticancer drugs on invasive capacity of human small-cell lung cancer cells in vitro. Nippon Ika Daigaku Zasshi 1995;64:320-328.

[6] Arai K, Lee SR, Lo H. Essential role for ERK Mitogen-activated protein kinase in matrix metalloprotease-9 regulation in rat cortical astocytes. Glia 2003;43:254-264.

14 - Urso et al. Effects of cisplatin on MMP-2 
[7] Mendes O, Kim HT, Lungu G, Stoica G. MMP-2 role in breast cancer brain metastasis development and its regulation by TIMP 2 and ERK1/2. Clin Exp Metastasis 2007;24:341-351.

[8] Nakamura H, Ueno H, Yamashita K, Shimada T, Yamamoto E, Fujimoto N, et al. Enhanced production and activation of progelatinase $A$ mediated by membrane-type 1 matrix metalloproteinase in human papillary thyroid carcinomas. Cancer Res 1999; 59:467-473.

[9] Muscella A, Urso L, Calabriso N, Vetrugno C, Fanizzi FP, Storelli C, Marsigliante S. Functions of epidermal growth factor receptor in cisplatin response of thyroid cells. Biochem Pharmacol 2009;77:979-992.

[10] Berlingieri MT, Santoro M, Battaglia C, Grieco M, Fusco A. The Adenovirus E1A gene blocks the differentiation of a thyroid epithelial cell line, however the neoplastic phenotype is achieved only after cooperation with other oncogenes. Oncogene 1993;8:249-255.

[11] Fusco A, Berlingieri MT, Di Fiore PP, Portella G, Grieco M, Vecchio G. One- and two-step transformations of rat thyroid epithelial cells by retroviral oncogenes. Mol Cell Biol 1987;7:3365-3370.

[12] Urso L, Muscella A, Calabriso N, Ciccarese A, Fanizzi FP, Storelli C. Marsigliante S. Differential functions of PKC-delta and PKC-zeta in cisplatin response of normal and transformed thyroid cells. Biochem Biophys Res Commun 2005;337:297-305.

[13] Muscella A, Marsigliante S, Verri T, Urso L, Dimitri C, Bottà G, et al. PKC-epsilondependent cytosol-to-membrane translocation of pendrin in rat thyroid $\mathrm{PC} \mathrm{Cl3}$ cells. J Cell Physiol 2008;217:103-112.

15 - Urso et al. Effects of cisplatin on MMP-2 
[14] Montiel M, Pérez de la Blanca E, Jiménez E. Angiotensin II induces focal adhesion kinase/paxillin phosphorylation and cell migration in human umbilical vein endothelial cells. Biochem Biophys Res Commun 2005;327: 971-978

[15] Katome T, Obata T, Matsushima R, Masuyama N, Cantley LC, Gotoh Y, et al. Use of RNA Interference-mediated Gene Silencing and Adenoviral Overexpression to Elucidate the Roles of AKT/Protein Kinase B Isoforms in Insulin Actions. J Biol Chem 2003;278:28312-28323.

[16] Muscella A, Urso L, Calabriso N, Ciccarese A, Migoni D, Fanizzi FP, et al. Differential response of normal, dedifferentiated and transformed thyroid cell lines to cisplatin treatment. Biochem Pharmacol 2005;71:50-60.

[17] Muscella A, Calabriso N, Fanizzi FP, De Pascali SA, Urso L, et al. [Pt $\left(\mathrm{O}, \mathrm{O}^{\prime}-\right.$ acac)(gamma-acac)(DMS)], a new Pt compound exerting fast cytotoxicity in MCF-7 breast cancer cells via the mitochondrial apoptotic pathway. $\mathrm{Br} J$ Pharmacol. 2008;153:34-49.

[18] Muscella A, Calabriso N, De Pascali SA, Urso L, Ciccarese A, Fanizzi FP, et al. New platinum(II) complexes containing both an O,O'-chelated acetylacetonate ligand and a sulfur ligand in the platinum coordination sphere induce apoptosis in HeLa cervical carcinoma cells. Biochem Pharmacol 2007;74:28-40.

[19] Lukashev ME, Werb Z. ECM signalling: orchestrating cell behaviour and misbehaviour. Trends Cell Biol 1998;8:437-441.

[20] Fini ME, Cook JR, Mohan R. Proteolytic mechanisms in corneal ulceration and repair. Arch Dermatol Res 1998;90:S12-S23.

16 - Urso et al. Effects of cisplatin on MMP-2 
[21] Hanemaaijer R, Verheijen JH, Maguire TM, Visser H, McDermott E, O'Higgins N, Duffy MJ._Increased gelatinase-A and gelatinase-B activities in malignant vs. benign breast tumors. Int J Cancer 2000;86:204-207.

[22] Tanimura S, Asato K, Fujishiro SH, Kohno M. Specific blockade of the ERK pathway inhibits the invasiveness of tumor cells: down-regulation of matrix metalloproteinase-3/9/-14 and CD44. Biochem Biophys Res Commun 2003;304:801-806.

[23] Liu JF, Crépin M, Liu JM, Ledoux D. FGF-2 and TPA induce matrix metalloproteinase-9 secretion in MCF-7 cells through PKC activation of the Ras/ERK pathway. Biochem Biophys Res Commun 22002;93:1174-1182.

[24] Pan MR, Hung WC. Nonsteroidal anti-inflammatory drugs inhibit matrix metalloproteinase-2 via suppression of the ERK/Sp1-mediated transcription. J Biol Chem 2002;277:32775-32780.

[25] Utani A, Momota Y, Endo H, Kasuya Y, Beck K, Nomizu M, Shinkai H. Laminin alpha 3 LG4 module induces matrix metalloproteinase-1 through mitogen-activated protein kinase signaling. J Biol Chem 2003;278:34483-34490.

[26] Esparza J, Vilardell C, Calvo J, Juan M, Vives J, Yagüe J, Cid MC. Fibronectin upregulates gelatinase B (MMP-9) and induces coordinated expression of gelatinase A (MMP-2) and its activator MT1-MMP by human T lymphocyte cell lines. A process repressed through RAS/MAP kinase signaling pathways. Blood 1999;94:2754-2766.

[27] Martiny-Baron G, Kazanietz MG, Mischak H, Hug H, Marme D, Schachtele C. Selective inhibition of protein kinase $C$ isozymes by the indolocarbazole Gö6976. J Biol Chem 1993;268:9194-9197.

17 - Urso et al. Effects of cisplatin on MMP-2 
[28] Sariahmetoglu M, Crawford BD, Sawicka J, Li L, Holmes C, Berthiaume LG, Holt A, Schulz R. Regulation of matrix metalloproteinase-2 (MMP-2) activity by phosphorylation, FASEB J 2007;21:2486-2495.

[29] Xie Z, Singh M, Siwik DA, Joyner WL, Singh K. Osteopontin inhibits interleukin-1 beta-stimulated increases in matrix metalloproteinase activity in adult rat cardiac fibroblasts: role of protein kinase C-zeta. J Biol Chem 2003;278:48546-48552.

[30] Lefranc F, Brotchi J, Kiss R. Possible future issues in the treatment of glioblastomas: special emphasis on cell migration and the resistance of migrating glioblastoma cells to apoptosis. J Clin Oncol 2005;23:2411-2422.

[31] Lucchesi PA, Sabri A, Belmadani S, Matrougui K. Involvement of metalloproteinases 2/9 in epidermal growth factor receptor transactivation in pressureinduced myogenic tone in mouse mesenteric resistance arteries. Circulation 2004;110:3587-3593.

[32] Visse $R$, Nagase $H$. Matrix metalloproteinases and tissue inhibitors of metalloproteinases: structure, function, and biochemistry. Circ Res 2003;92:827-839.

18 - Urso et al. Effects of cisplatin on MMP-2 


\section{LEGENDS TO FIGURES}

\section{Fig 1. - The effects of cisPt on MMP-2 expressed by PC E1Araf cells}

(A) Conditioned media $(\mathrm{CM})$ or cell lysate $(\mathrm{CL})$ from $\mathrm{PC}$ E1Araf were analysed by gelatin zymography. (B) Cells were treated without or with cisPt (10 and $100 \mu \mathrm{M})$ for $4 \mathrm{~h}$ or $(\mathrm{C})$ with $100 \mu \mathrm{M}$ for different time periods and cell lysate and conditioned media (B) or conditioned media only (C) were analysed by gelatin zymography. (D) Cell lysates were electrophoresed on 10\% SDS-polyacrylamide gels and analysed by Western blotting using the antibody against the MMP-2 protein. To confirm equal protein loading in Western blot, the membranes were re probed with $\beta$-actin antibody. (E, F) PC E1Araf cells were incubated without or with $100 \mu \mathrm{M}$ cisPt for different time periods and then RNA was extracted. (E) $\beta$-Actin levels normalised the amount of DNA template used in each PCR reaction. $(F)$ The samples were also analysed using real-time PCR. mRNA levels were normalised to $\beta$-actin and calculated as fold change values relative to control. Data were expressed as mean standard error of three different experiments.

The figures are representative of four independent experiments.

\section{Fig 2. - The effects of PKC inhibitors on MMP-2 expressed by PC E1 Araf cells}

(A) Cells were treated without or with PD98059 (15-30 $\mu \mathrm{M})$ for $30 \mathrm{~min}$, and $4 \mathrm{~h}$ later conditioned media was analysed by gelatin zymography. (B) Cells pre-treated for $30 \mathrm{~min}$ with $30 \mu \mathrm{M}$ PD98059 were incubated with $100 \mu \mathrm{M}$ cisPt for $4 \mathrm{~h}$ and then MMP-2 gelatinolytic activity was assessed in both conditioned medium and cell lysates. (C) Cell lysates from PC E1Araf pre-treated with $30 \mu \mathrm{M}$ PD98059 and then with $100 \mu \mathrm{M}$ cisPt were electrophoresed on 10\% SDS-polyacrylamide gels and analysed by Western blotting using the antibody against the MMP-2 protein. (D) Cells were pre incubated for 30 min with 0.1-10 $\mu \mathrm{M}$ GF109203X (inhibitor of all PKC isoforms,) or (E) with 10 and 20 $\mu \mathrm{M}$ rottlerin (Rot, inhibitor of PKC- $\delta$ ) or $(F)$ with 0.1 and $1 \mu \mathrm{M}$ Gö6976 (inhibitor of conventional, calcium dependent PKCs) or (G) with increasing concentrations of a synthetic myristoylated pseudo substrate of PKC- $\zeta(\zeta-P S)$ for 60 min; afterwards, cisPt

19 - Urso et al. Effects of cisplatin on MMP-2 
was added for $4 \mathrm{~h}$ and then MMP-2 gelatinolytic activity was assessed in conditioned medium.

The figures are representative of four independent experiments.

\section{Fig 3. - The effect of PKC- $\zeta$ and AKT on MMP-2 expressed by PC E1Araf cells}

(A) Cells were transfected with siRNA-PKC- $\zeta$ and siRNA-NS using "Code Breaker transfection reagent" (Promega) for $4 \mathrm{~h}$. Then, fresh medium was added and PKC- $\zeta$ expression was analysed after 24 hours by Western blotting using the antibody against the PKC- $\zeta$ isozyme. (B) Conditioned media from siRNA-PKC- $\zeta$-transfected cells incubated with $100 \mu \mathrm{M}$ cisPt for $4 \mathrm{~h}$ were analysed by gelatin zymography. (C) Cells were treated or not with $100 \mu \mathrm{M}$ cisPt for the indicated time intervals; cell fractions (cytosol, cyt or membranes, mem) were analysed by western blotting with specific antiPKC- $\zeta$ antibody. (D) Conditioned media from cells treated with the inhibitor of PI3K (LY294002) or from cells siRNA-AKT-transfected were incubated or not with $100 \mu \mathrm{M}$ cisPt for $4 \mathrm{~h}$ and then analysed by gelatin zymography. (E) Cells were transfected with siRNA-AKT and siRNA-NS using "Code Breaker transfection reagent" (Promega) for 4 hours. Then, fresh medium was added and AKT expression was analysed after 24 hours by Western blotting using the antibody against the AKT isozymes.

To confirm equal cytosolic protein loading the blots in $A, C$ and $E$ were stripped and re probed with an anti- $\beta$-actin monoclonal antibody; blots in $C$ were also re probed with an anti-alpha subunit of $\mathrm{Na}^{+} / \mathrm{K}^{+}$ATPase antibody to confirm equal membrane protein loading. The figures are representative of three independent experiments.

\section{Fig 4. Effects of cisPt and MMP-2 on PC E1Araf cell migration and viability}

(A) Cells were treated with 10 and $100 \mu \mathrm{M}$ cisPt and real time monitoring of migration through a modified Boyden chamber was performed. Cells in the upper half of the chamber were allowed to migrate through a porous membrane toward the lower chamber containing serum-free medium (white circle, Control -) or $10 \%$-serum medium (black circle, Control + ) as chemoattractant. The data are means \pm SD of four experiments run in triplicates and are expressed as a percentage of negative control 
(well without serum in lower chamber as chemoattractant). Inset: representative fluorescent images of cells migrated through the membrane insert after 1,5 and $4 \mathrm{~h}$, treated or not with $100 \mu \mathrm{M}$ cisPt (magnification X30). (B) Cells were transfected with siRNA-MMP-2 and siRNA-NS for 4 hours. Then, fresh medium was added and MMP-2 expression was analysed after 24 hours by Western blotting using the antibody against MMP-2. (C) Migration assay (at $4 \mathrm{~h}$ ) through a modified Boyden chamber was performed on cells transfected with siRNA-MMP-2 or siRNA-PKC- $\zeta$ or siRNA-NS for 4 hours, and on cells pre-incubated with the MMP-2 inhibitor I for $60 \mathrm{~min}$. Finally, PC E1Araf cells were incubated with $100 \mu \mathrm{M}$ cisPt for $4 \mathrm{~h}$ and then with either control medium or medium containing mouse MMP-2 active protein. (D) Cells were transfected with siRNA-MMP-2 (+) or with siRNA-NS (-) for 4 hours. Then, $100 \mu \mathrm{M}$ cisPt in fresh medium was added and after $4 \mathrm{~h}$ viable cell numbers assessed by the MTT assay. Mouse MMP-2 active protein was also added to control cells. (E) Cells were treated or not with $100 \mu \mathrm{M} \mathrm{cisPt}$ or with $100 \mu \mathrm{M}\left[\mathrm{Pt}\left(\mathrm{O}, \mathrm{O}^{\prime}-\mathrm{acac}\right)(\mathrm{Y}\right.$-acac)(DMS)] (Pt-2(acac)) for the indicated time intervals. On total lysates western blotting was performed with anti-caspase-7 antibody, whilst nuclear fractions were analysed by western blotting with anti-PARP polyclonal antibody.

$A, C$ and $D$ : data are means \pm SD of four different experiments run in four replicates and are presented as percent of control. Statistical analysis was carried out using the ANOVA, and values with shared letters are not significantly different according to Bonferroni/Dunn post hoc tests. Representative immunoblots of three experiments are depicted.

21 - Urso et al. Effects of cisplatin on MMP-2 


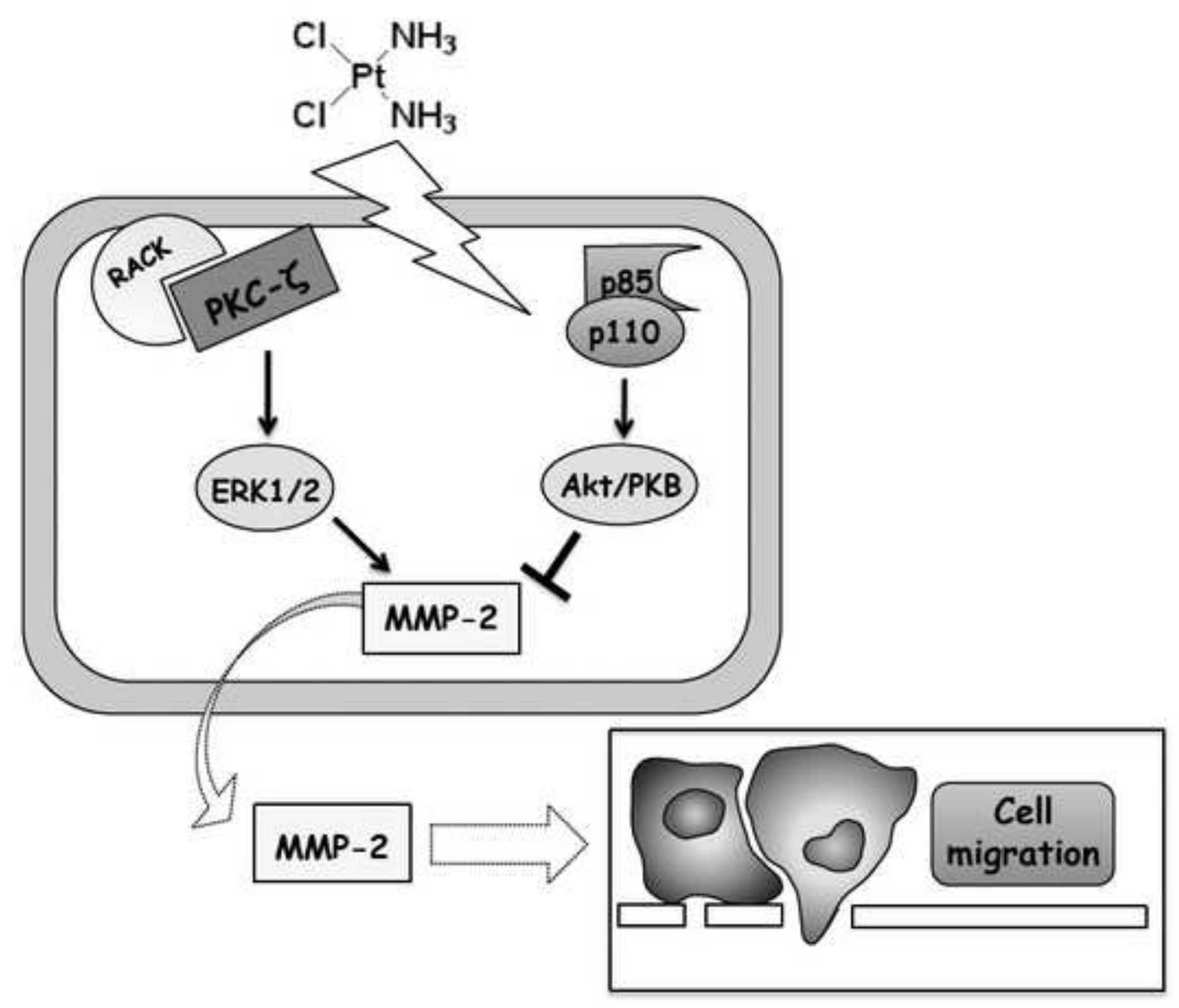

MMP-2 expression and function in PC E1Araf cells are differently regulated by PKC-C/ERK and PI3K/AKT pathways. CisPt provokes the inhibition of MMP-2 secretion ending in cell migration decrease 
A

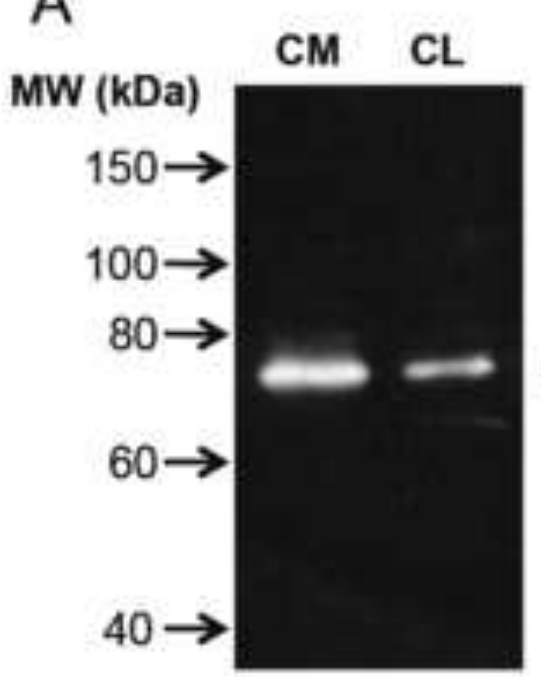

B Cell Medium Cell Lysates

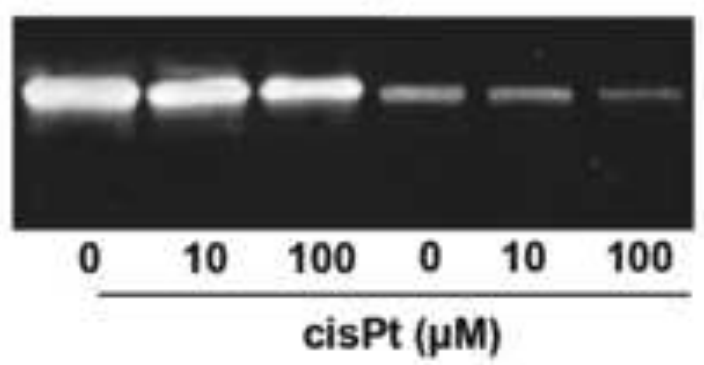

C

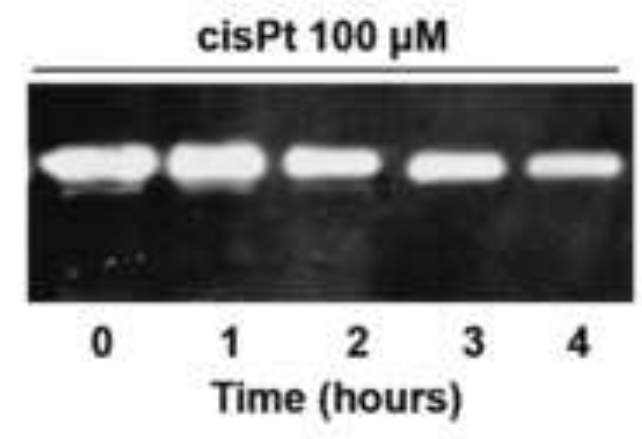

D

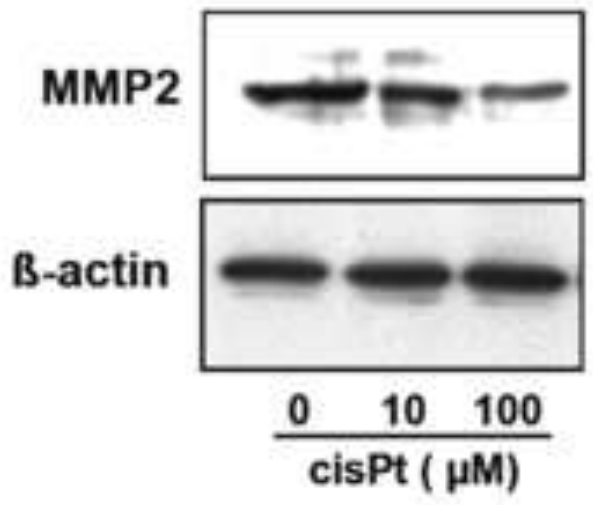

E

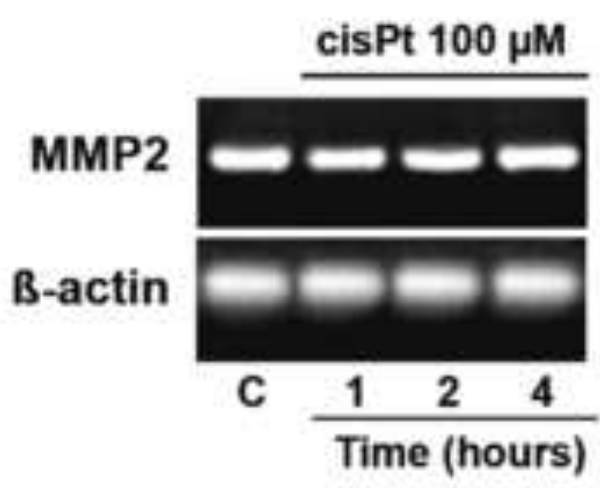

F

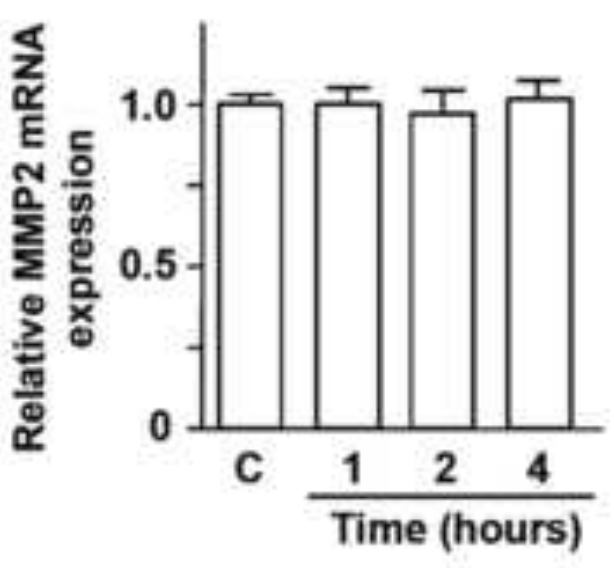


A $B$

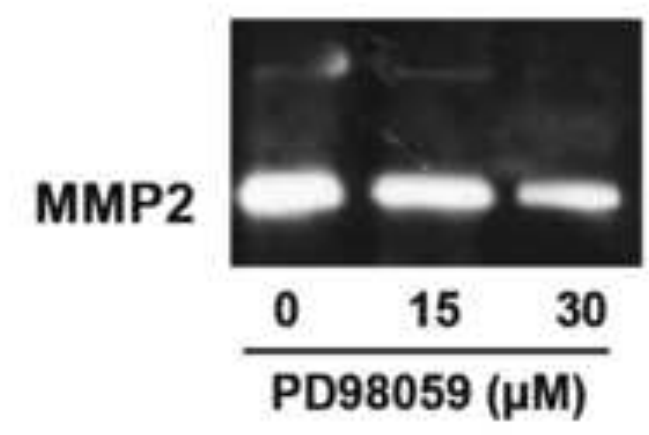

B

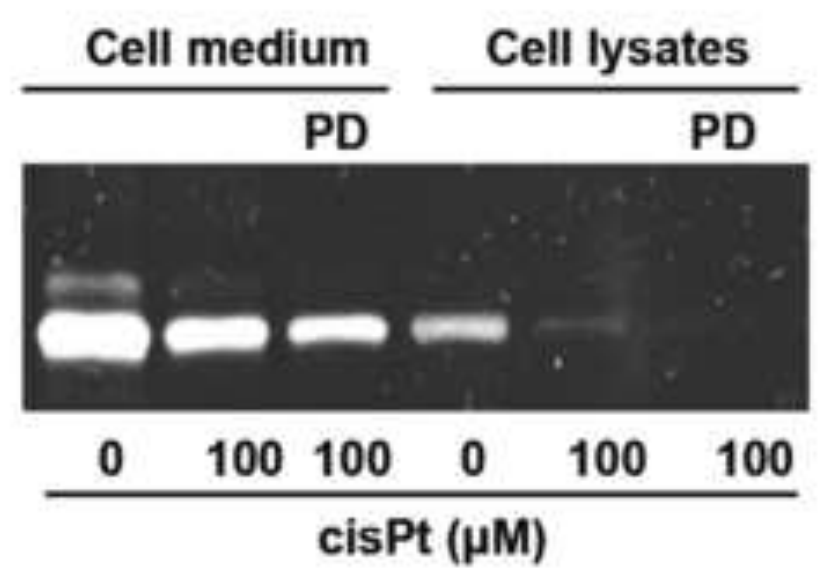

C

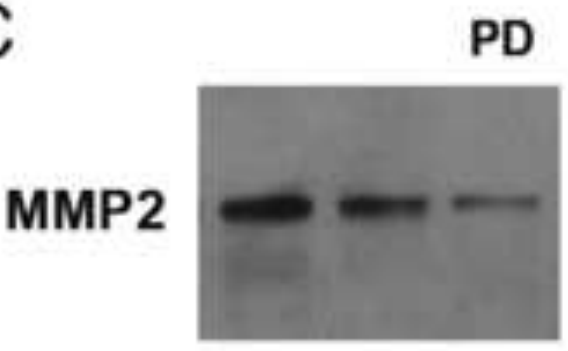

B-actin

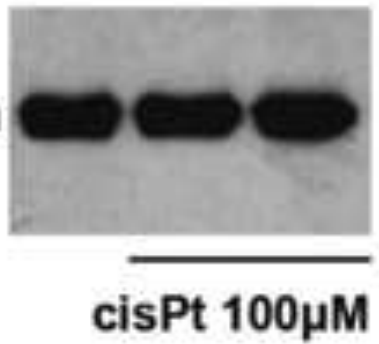

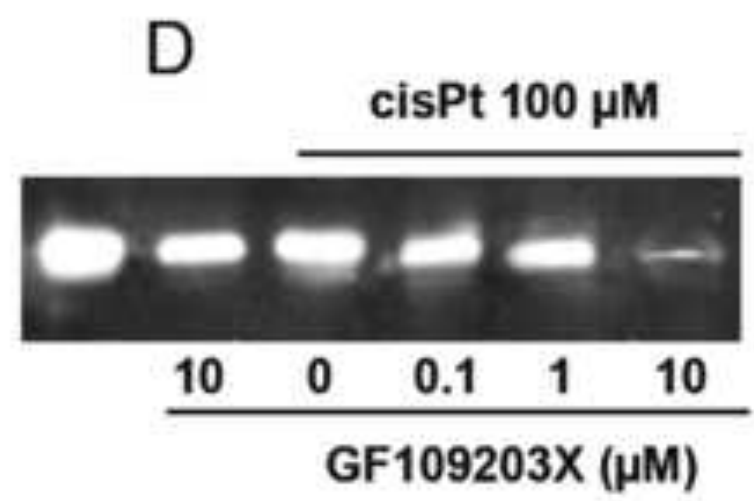

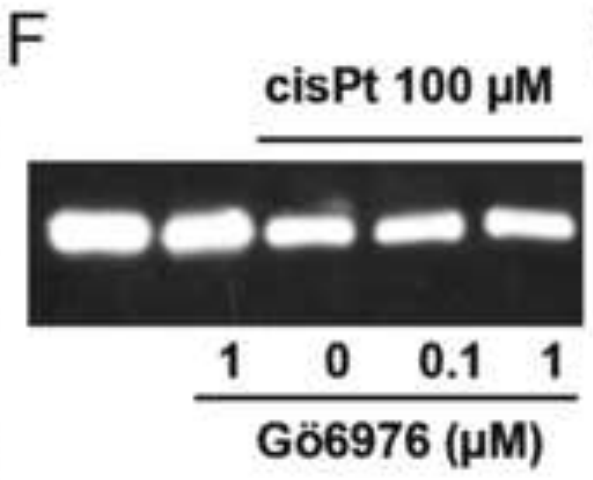

G cisPt $100 \mu \mathrm{M}$

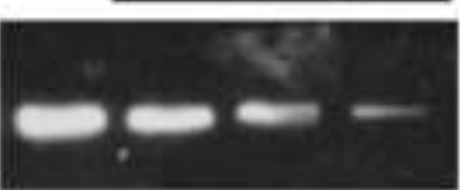

$50 \quad 100$

PS- $\zeta(\mu \mathrm{M})$

Fig 2 

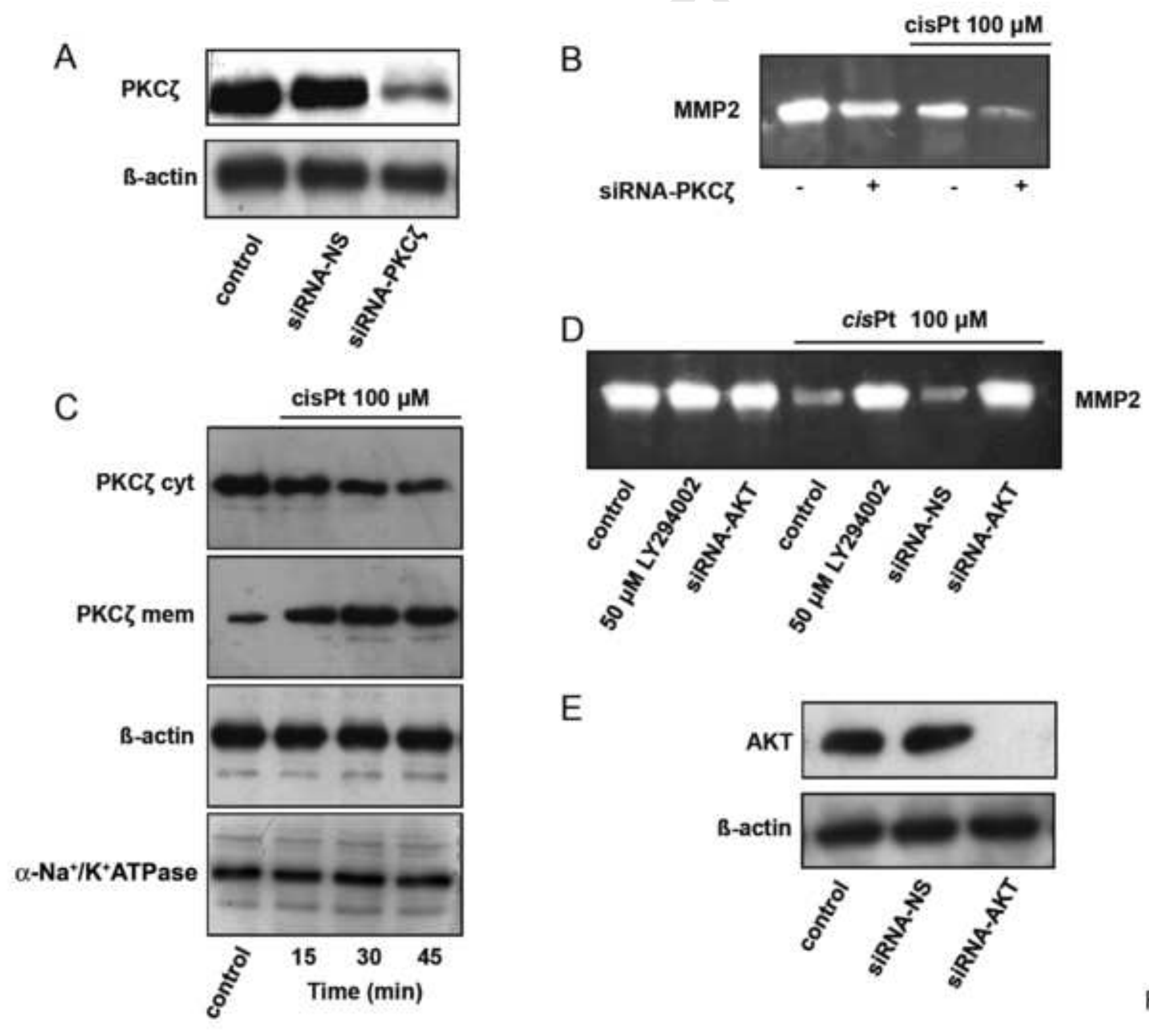

E

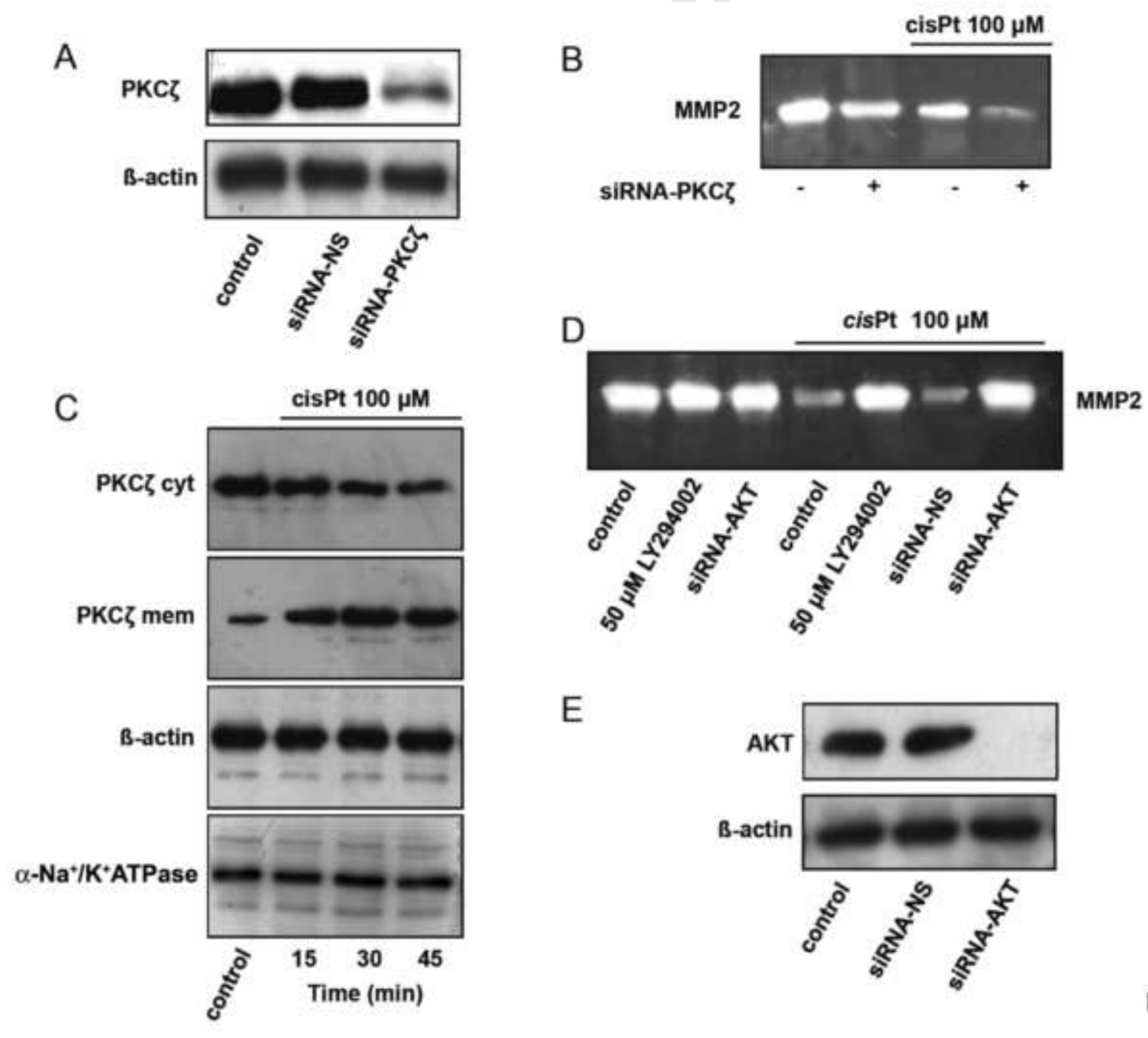

Fig 3

rage $2 \zeta$ or $2 b$ 
A
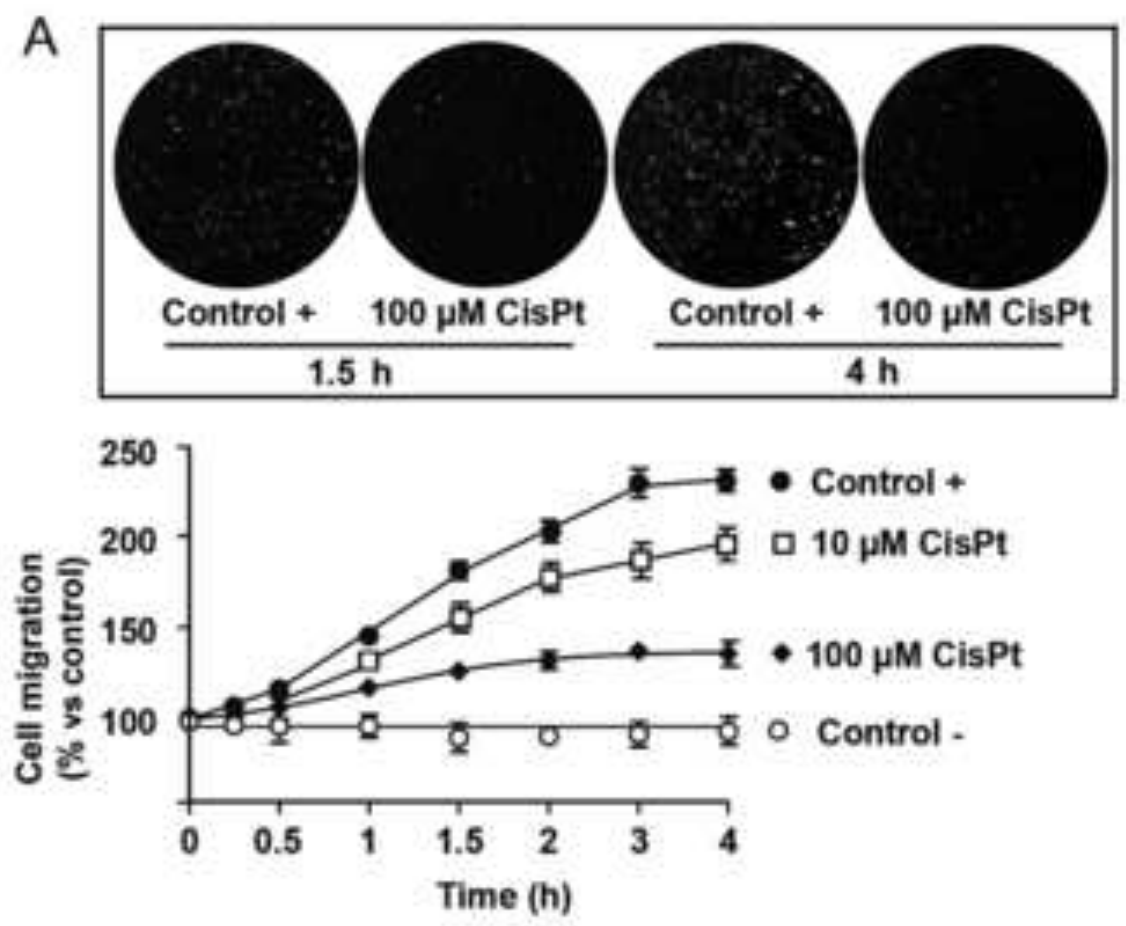

C

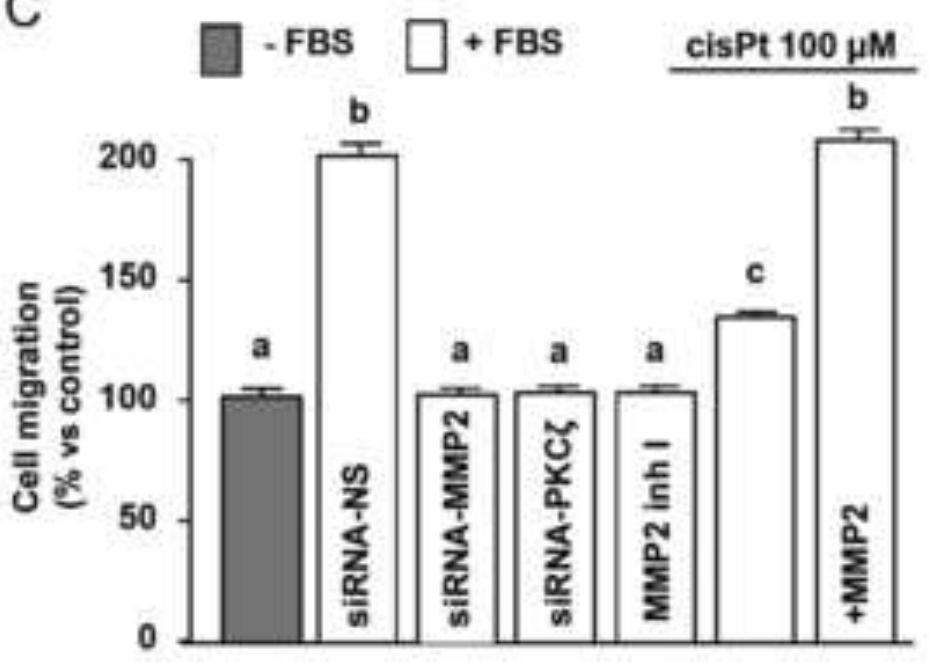

B

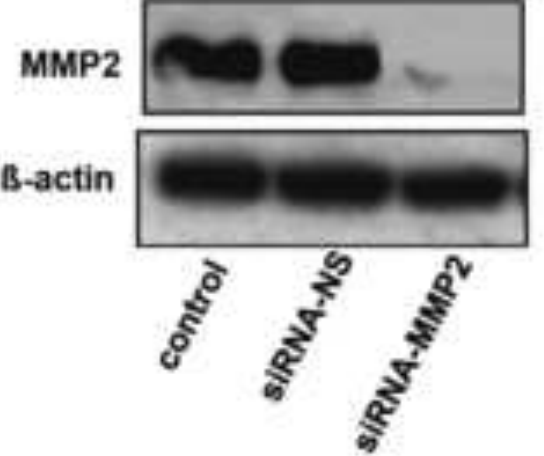

D

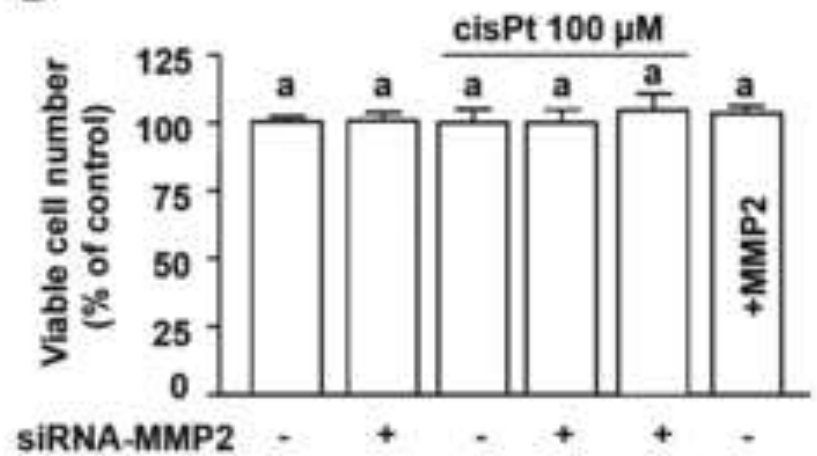

E

Casp-7 cisPt $100 \mu \mathrm{M} \quad$ cisPt $100 \mu \mathrm{M}$ PARP $35 \mathrm{kDa} D \mathrm{kDa}$
2000

Casp-7 P(-2(acac) $100 \mu \mathrm{M} \quad$ Pt-2(acac) $100 \mu \mathrm{M}$ PARP $35 \mathrm{kDa}$ $20 \mathrm{kDa}$

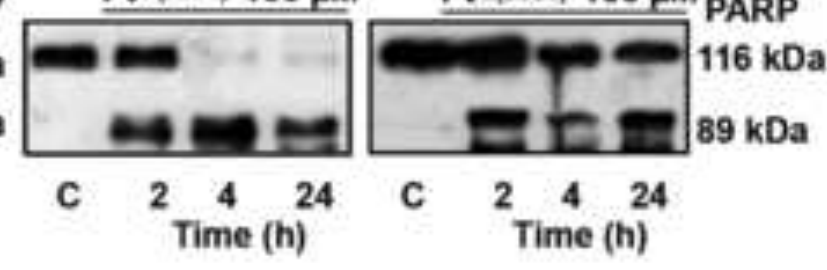

Fig 4 